\title{
PENGEMBANGAN MODUL MATEMATIKA DAN PELATIHAN PENYELESAIAN SOAL BERTIPE OLIMPIADE UNTUK TINGKAT SMA
}

\author{
Palupi Sri Wijayanti \\ Pendidikan Matematika, Fakultas Keguruan dan Ilmu Pendidikan, Universitas PGRI Yogyakarta \\ e-mail: palupi@upy.ac.id
}

\begin{abstract}
Abstrak
Pengabdian ini bertujuan untuk memberikan pelatihan dalam menyelesaikan permasalahan dengan soal yang memiliki tipe olimpiade di tingkat SMA. Selain itu, bertujuan juga untuk mengembangkan modul matematika yang dapat digunakan dalam menyelesaikan persoalan yang berkaitan dengan olimpiade. Langkah-langkah pengabdian dilakukan dengan tahap koordinasi, pengembangan, pelaksanaan, dan evaluasi. Hasil pengabdian menunjukkan bahwa pengembangan modul matematika memiliki kevalidan yang ditunjukkan dengan rata-rata 3,7 sehingga dapat dikatakan modul matematika yang telah dikembangkan layak digunakan dalam pembelajaran. Selanjutnya, hasil pengabdian yang memberikan pelatihan penyelesaian soal matematika bertipe olimpiade menunjukkan bahwa respon guru dan siswa termasuk dalam kategori sangat baik yang direpresentasikan dengan rata-rata 3,74 dan 3,78.
\end{abstract}

Kata Kunci: Pengembangan Modul, Soal Olimpiade, dan Modul Matematika

\begin{abstract}
This service aims to provide training in solving problems with questions with an Olympic type at the high school level. Besides, it also seeks to develop a math module that can solve problems related to the Olympics. The service steps were carried out in the coordination, development, implementation and evaluation stages. The results show that the development of the mathematics module has validity, indicated by an average of 3.7. It categorized the mathematics module that has been developed is suitable for use in learning. Furthermore, the service results showed that teachers' and students'responses were in the excellent category. It is represented by an average of 3.74 and 3.78 .
\end{abstract}

Keywords: Development of module; Olympic questions, Mathematics module

\section{PENDAHULUAN}

Kurikulum matematika di sekolah menengah baik atas dan pertama bertujuan untuk memfasilitasi para siswa dalam menambah wawasan dan pengalaman untuk menyelesaikan permasalahan yang membutuhkan penalaran logis serta kritis. Sehingga pemberian jadwal mata pelajaran matematika di sekolah menengah atas (SMA) terbagi dalam karakteristik matematika wajib dan peminatan. Kurikulum yang dirancang seperti ini ditujukan untuk menciptakan bangsa Indonesia menjadi warga Negara yang memiliki bekal dalam kemampuannya untuk bertahan hidup baik dari segi iman, kreatifitas, memiliki inovasi, produktif, serta memiliki sikap yang afektif untuk selalu berkontribusi dalam hidup berbangsa dan (Srifitriani, 2020). Dalam proses pembelajaran mata pelajaran matematika terdapat yang sangat penting dan perlu diperhatikan yaitu proses pemecahan masalah yang terkadang disebut sebagai jantung matematika (Widyastuti, 2015). Dukungan lain dari pihak World Economic Forum menyebutkan bahwa alumni atau lulusan siswa dapat berhasil dengan lancar dan sukses dalam berkompetisi di dunia kerja apabila menguasi kemampuan dalam berkolaborasi, memecahkan permasalahan dengan baik, dan dapat berkomunikasi dengan lancar (Pratiwi, 2020).

Pemberian ruang belajar yang kondusif bagi siswa sangatlah diperlukan sebagai bentuk dari implementasi kurikulum 2013 pada seluruh mata pelajaran termasuk matematika. Dalam standar kompetensi lulusan SMA disebutkan bahwa pelajaran yang diterima para siswa harus memberikan kedalaman yang dapat meningkatkan kompetensi siswa baik dari dimensi sikap, pengetahuan, dan keterampilan. Dimensi pengetahuan harus mencakup unsur fakta, konsep, procedur, prinsip 
maupun metakognisi. Dimensi keterampilan akan beriringan bersama dengan pengetahuan yang diolah dalam proses pembelajaran sehingga dapat meningkatkan proses berfikir siswa baik dari tingkatan memahami, menerapkan, menganalisis, mengevaluasi, hingga mencipta atau berkreasi (Anggraena, 2019). Hal tersebut selanjutnya berdampak pada perencanaan proses pembelajaran yang dikemas dengan pengembangan materi berdasarkan kompetensi dasar hingga penentuan indikator pencapaian kompetensi yang linier (Wijaya et al., 2020).

Dalam proses pembelajaran matematika, Bapak/Ibu guru selalu memberikan ruang bagi siswa untuk mengekplorasi segala macam sumber belajar sehingga dapat memicu untuk memunculkan motivasi, bakat, dan minat yang dimiliki para siswa (Sunaryati \& Lataami, 2020). Bakat dan minat siswa yang termotivasi untuk selalu berkompetisi akan mendorong para siswa agar selalu belajar dan memperdalam pengetahuan dalam wadah kelompok belajar olimpiade matematika. Dalam kelompok tersebut para siswa dapat secara langsung berdiskusi untuk selalu meningkatkan kemampuan dan prestasi untuk menemukan solusi masalah dengan cepat dan tepat (Lestari et al., 2019).

Kegiatan Olimpiade matematika telah secara rutin diadakan baik dari tingkat sekolah, kecamatan, kabupaten, provinsi, maupun hingga nasional. Kegiatan olimpiade ini merupakan bentuk upaya pemerintah untuk menuntaskan wajib belajar yang berkualitas (Setiawan et al., 2018). Selain itu, kegiatan olimpiade ini dapat menjadi wahana bagi para siswa dalam mengembangkan kompetensi akademiknya dan kebaraniannya untuk bersaing hingga taraf internasional.

Kegaitan kelompok belajar yang ada di sekolah-sekolah terkadang kurang terfasilitasi dengan baik dikarenakan beberapa hal diantaranya kesibukan kegiatan sekolah baik dari guru maupun keterlibatan para siswa dalam kompetisi serta ekstrakurikuler yang lain. Hal ini berdampak kepada kurangnya wawasan dalam menghadapi permasalahan soal bertipe olimpiade sehingga pencapaian kejuaraan terkadang tidak sampai dengan maksimal. Hal tersebut di rasakah oleh MAU Al-Imdad. Karena itulah kegiatan pengabdian ini dilaksanakan sehingga dapat memberikan efek serta dampak positif bagi atmosfer pembelajaran matematika di kelas. Selain itu, kegiatan pengabdian ini juga memiliki tujuan yang akan menyaring bibit-bibit potensial untuk bersaing di tingkat kabupaten hingga nasional.

\section{METODE}

Pengabdian dalam rangka untuk mengembangkan modul matematika sebagai media dalam melatih para siswa untuk menyelesaikan permasalahan bertipe olimpiade dilakukan melalui empat tahap. Tahapan tersebut yaitu: koordinasi, pengembangan, pelaksanaan, dan evaluasi. Tahap koordinasi dilakukan dengan berkomunikasi secara bersama dengan pihak sekolah yaitu MA Unggulan Al Imdad Bantul untuk menentukan hari pelaksanaan pengabdian. Dari hasil koordinasi bersama diperoleh kesepakatan pelaksanaan pengabdian dilakukan selama tiga hari. Adapun peserta yang terlibat adalah siswa kelas XII MIA beserta Bapak/Ibu guru matematika pendamping pelaksanaan kegiatan pengabdian.

Tahap selanjutnya adalah pengembangan modul matematika. Pada tahap ini, pengabdi melakukan desain modul matematika yang akan digunakan dalam pengabdian untuk pelatihan penyelesaian soal matematika bertipe olimpiade. Desain yang telah disusun kemudian divalidasi oleh ahli media dan ahli materi. Tim ahli sebagai validator adalah rekan sejawat di program studi pendidikan matematika Universitas PGRI Yogyakarta.

Setelah modul yang dikembangkan memperoleh kevalidan dari tim ahli, maka pengabdi akan melaksanakan pengabdian di sekolah dengan kegiatan pelatihan penyelesaian soal matematika bertipe olimpiade. Pelatihan ini memfasilitasi para siswa dengan menghadapkan beberapa jenis soal-soal yang sering digunakan dalam kompetisi olimpiade matematika.

Sebagai bentuk refleksi dari kegiatan pengabdian, maka dilakukan evaluasi untuk mengetahui respon para peserta baik dari guru maupun siswa. Evaluasi dilakukan dengan memberikan angket respon yang memuat indicator dari pelaksanaan pelatihan dengan menggunakan modul matematika. Hasil analisis angket dihitung dengan menemukan skor rerata setiap indicator untuk ditentukan kategori pelaksanaan dan penggunaan modul. 


\section{HASIL DAN PEMBAHASAN}

Kegiatan pengabdian yang telah dilakukan oleh pengabdi dari Universitas PGRI Yogyakarta diawali dengan menemukan permasalahan yang berhubungan dengan kemampuan awal matematika siswa SMA dalam partisipasinya untuk berkompetisi melalui kegiatan olimpiade. Kemudian masuklah pada tahap koordinasi yang dilakukan dengan berdiskusi bersama dengan para Bapak/Ibu guru untuk menentukan jadwal pelaksanaan pengabdian. Hasil koordinasi menyebutkan pelaksanaan pengabdian dilakukan pada hari kamis, jumat, dan Sabtu pada tanggal 29-31 Januari 2020, pukul 08.10 - 09.20 WIB. Pelaksanaan pengabdian ini dilakukan pada bulanbulan awal karena jadwal pengumuman untuk diadakan kompetisi adalah bulan Maret atau April.

Tahapan pengabdian selanjutnya adalah fase pengembangan. Tahapan ini bertujuan untuk mengembangkan produk yaitu modul matematika yang memuat soal-soal dengan tipe olimpiade. Adapun hasil proses pengembangan menunjukkan bahwa modul yang digunakan sangat layak. Hal ini dinyatakan berdasarkan hasil validasi yang diberikan oleh para tim ahli materi maupun media dengan rangkuman penilaian sebagai berikut.

Tabel 1. Hasil Analisis untuk Kevalidan Modul

\begin{tabular}{|l|l|c|c|c|c|}
\hline No. & \multicolumn{1}{|c|}{ Indikator } & \multicolumn{2}{|c|}{ Skor Validator } & Rata-rata per & Ket \\
\cline { 2 - 6 } & & Media & Materi & indikator & \\
\hline 1 & Penggunaan Bahasa & 3,28 & 3,42 & 3,36 & Sangat Valid dan tidak revisi \\
\hline 2 & $\begin{array}{l}\text { Pemberian Contoh dan } \\
\text { Soal Latihan }\end{array}$ & 4 & 4 & 4 & Sangat Valid dan tidak revisi \\
\hline 3 & $\begin{array}{l}\text { Penyampaian materi yang } \\
\text { mudah dipahami }\end{array}$ & 3,87 & 3,75 & 3,62 & Sangat Valid dan tidak revisi \\
\hline 4 & $\begin{array}{l}\text { Penggunaan prinsip } \\
\text { kontekstual dalam materi }\end{array}$ & 4 & 4 & 4 & Sangat Valid dan tidak revisi \\
\hline 5 & $\begin{array}{l}\text { Pemberian evaluasi dan } \\
\text { feedback }\end{array}$ & 3,33 & 3,67 & 3,50 & Sangat Valid dan tidak revisi \\
\hline & Nilai rata-rata & & 3,70 & Sangat Valid dan tidak revisi \\
\hline
\end{tabular}

Rata-rata skor kevalidan yang diperoleh saat pengembangan modul dengan skor 3,70 menunjukkan bahwa modul siap digunakan sehingga dapat digunakan secara langsung untuk pelatihan penyelesaian soal olimpiade. Tahap pelatihan penyelesaian soal bertipe olimpiade sangat menantang dan menarik perhatian siswa karena jarang menemui dan terlihat bahwa materi matematika sangatlah beragam dan menarik.

Tahap pelaksanaan dilakukan selama 3 kali pertemuan dengan pertemuan terakhir adalah pengambilan nilai atau disebut dengan tes. Sebagai bahan perbaikan dalam penggunaan dan pengembangan modul, maka pengabdi memberikan angket kepada peserta untuk mengetahui ada rekomendasi yang sebaiknya dilakukan. Adapun hasil angket disajikan pada tabel sebagai berikut.

Tabel 2. Hasil Analisis Angket Peserta Pengabdian

\begin{tabular}{|c|c|c|c|c|}
\hline No. & Indikator & \multicolumn{2}{|c|}{ Rata-rata Per Indikator } & Ket \\
\hline & & Guru & Siswa & \\
\hline 1 & Bahasa dan Komunikasi & 3,62 & 3,59 & Sangat Baik \\
\hline 2 & Tujuan pencapaian pembelajaran & 3,70 & 3,78 & Sangat Baik \\
\hline 3 & Materi yang disampaikan & 3,89 & 3,98 & Sangat Baik \\
\hline & Kesimpulan & 3,74 & 3,78 & Sangat Baik \\
\hline
\end{tabular}

Analisis hasil angket dari respon guru dan siswa terhadap penggunaanya untuk memfasilitasi dalam penyelesaian soal matematika bertipe olimpiade dilihat dari indikator penggunaan bahasa dalam mengkomunikasikan materi, penyampaian tujuan pembelajaran, dan penyampaian materi yang mudah dipahami. Berdasarkan hasil analisis tersebut, diperoleh kesimpulan bahwa modul yang digunakan dalam pengabdian tergolong dalam kategori sangat baik dan dapat diaplikasikan dalam pembelajaran untuk mendukung permasalahan olimpiade matematika. Hasil tersebut tidak berbeda dengan pendapat yang disebutkan oleh Zulfikar (2019) 
yang berpendapat bahwa penggunaan media yang menarik dapat memberikan kesan kepada para siswa sehingga akan lebih mudah dalam memahami serta menerima informasi materi yang disampaikan oleh Bapak/Ibu guru selama pembelajaran berlangsung. Para peserta bahkan dapat meningkatkan kompetensi mereka dalam melakukan analisis permasalahan bertipe olimpiade dan menyelesaikannya secara efektif (Susilawati et al., 2019).

Sebagai tambahan bahan evaluasi, pengabdi memberikan pertanyaan singkat selama proses pelaksanaan dan pengambilan data angket. Pertanyaan tersebut mengenai adanya tambahan wawasan yang diperoleh para siswa. Demikian pelaksanaan pengabdian yang telah dilakukan oleh pengabdi dari tahap koordinasi, pengembangan, pelaksanaan, dan evaluasi. Secara garis besar, kegiatan pengabdian berjalan lancar dengan kondisi peserta yang sangat kondusif dan partisipatif. Hasil pengabdian secara langsung dapat dirasakan dan diterima oleh seluruh peserta dan diharapkan sekolah dapat melakukan penjadwalan pembelajaran pengayaan dengan tipe permasalahan setingkat olimpiade matematika.

\section{SIMPULAN}

Berdasarkan pelaksanakan pengabdian dan hasil pembahasan, maka pengabdi mengambil kesimpulan sebagai berikut.

1. Pengembangan modul matematika yang memuat soal bertipe olimpiade SMA termasuk dalam kategori sangat layak digunakan dengan representasi rata-rata skor kevalidan 3,70.

2. Pelaksanaan pengabdian untuk melatih para siswa dalam menyelesaiakan soal matematika bertipe olimpiade berlangsung secara lancar dengan respon siswa dan guru yang menyatakan bahwa kegiatan pengabdian ini bermanfaat bagi mereka dalam memperkaya pengetahuan serta wawasan yang berkaitan dengan olimpiade matematika.

\section{SARAN}

Sebagai bentuk tindak lanjut, maka pengabdi memberikan rekomendasi bahwa pengembangan modul matematika tidak hanya untuk soal dengan tipe olimpiade namun perlu untuk materi pelajaran matematika di kelas yang diperkaya dengan permasalahan kontekstual dari berbagai sumber.

\section{DAFTAR PUSTAKA}

Anggraena, Y. (2019). Pengembangan Kurikulum Matematika Untuk Meningkatkan Kemampuan Siswa Dalam Penalaran Dan Pemecahan Masalah. Alifmatika: Jurnal Pendidikan Dan Pembelajaran Matematika, 1(1), 15-27. https://doi.org/10.35316/alifmatika.2019.v1i1.15-27

Lestari, I., Andinny, Y., \& Mailizar, M. (2019). Pengaruh Model Pembelajaran Situation Based Learning dan Kemandirian Belajar Terhadap Kemampuan Pemecahan Masalah Matematis. JNPM (Jurnal Nasional Pendidikan Matematika), 3(1), 95. https://doi.org/10.33603/jnpm.v3i1.1748

Pratiwi, C. P. (2020). JPE (Jurnal Pendidikan Edutama) Vol . 7 No . 1 Januari 2020 ANALISIS KETERAMPILAN MEMBACA PERMULAAN SISWA SEKOLAH. 7(1), 1-8.

Setiawan, Y. B., Hapizah, H., \& Hiltrimartin, C. (2018). Kesalahan siswa dalam menyelesaikan soal Olimpiade SMP konten aljabar Students ' error in solving junior high school Olympiad problem on algebra content. Jurnal Riset Pendidikan Matematika, 5(2), 3.

Srifitriani, A. (2020). Pelatihan Penerapan Kurikulum 2013 Guru Sekolah Dasar Negeri Dengan Metode Pendampingan. 2(April), 16-25.

Sunaryati, S., \& Lataami, A. (2020). Hubungan Konsep Diri Dan Motivasi Belajar Dengan Kemampuan Berpikir Divergen Biologi Siswa SMA Negeri 1 Makassar. JIKAP PGSD: Jurnal Ilmiah Ilmu Kependidikan, 4(1), 95. https://doi.org/10.26858/jkp.v4i1.12056

Susilawati, S., Doyan, A., \& Taufik, M. (2019). Pengayaan Materi Olimpiade Fisika dan Pelatihan Penyelesaian Soal-Soal Olimpiade Fisika Bagi Guru dan Siswa di Sekolah Mitra. Jurnal Pengabdian Magister Pendidikan IPA, 2(1), 1-5. https://doi.org/10.29303/jpmpi.v2i1.315

Widyastuti, R. (2015). Proses Berpikir Siswa dalam Menyelesaikan Masalah Matematika berdasarkan Teori Polya ditinjau dari Adversity Quotient Tipe Climber. Al-Jabar: Jurnal Pendidikan Matematika, 6(2), 183-194.

Wijaya, I. P., Kurniawati, E., Iswantiningtyas, V., \& Dwiyanti, L. (2020). WORKSHOP 
PERENCANAAN PEMBELAJARAN PENDIDIKAN ANAK USIA DINI BERBASIS LOOSE PARTS. 1(2), 84-88.

Zulfikar, RN. 2019. Pengaruh Pendekatan Metakognitif Terhadap Kemampuan Representasi Siswa Dalam Pembelajaran Matematika SMK Kesehatan Nusantara Kupang. Jurnal Inovasi Matematika (Inomatika) 1, (2) Hal 91-98 